\title{
シールドセグメントの応力に対する継手剛性の影響 \\ EFFECT OF JOINT RIGIDITY ON THE STRESSES \\ IN LININGS FOR SHIELD TUNNELLING
}

.

要 旨 シールド セグメントの継手の剛性がセグ メント本体部に比して小さい場合，このセグメントを千 鳥に組んだトンネルに土圧が作用すると, リングどうし の継手のボルトにはせん断力が生じ, セグメントリン グの応力, たわみは継手のない一様なリングよりも大き くなる。

ここでは, 継手剛性の低下によるセグメントリング の応力, たわみの増加を理論的に求め, 実験により理論 の妥当性を検証した。

\section{1.はじめに}

シールド工法におけるトンネルは, セグメントどうし をボルトで結合（「セグメント継手」と呼ぶ）してリン グを組み上げ，このリングを「軸方向ボルト」で連結し てトンネルを形成しているが，一般に「セグメント継 手」の剛性, 強度はセグメント本体部に比して劣ってい る場合が多く, そのためこの部分の弱点をカバーし, リ ングの変形を少なくするために, リングどうしは「セグ メント継手」がトンネル軸方向に通らないように千鳥に 連結されている。このために，トンネルに外圧が作用す ると,「軸方向ボルト」により相隣るリングが互いに変 形を拘束されるため, このボルトにはせん断力が作用す る。このせん断力を $Q / 2$ とすると, リングには結局 $Q$ なる力が「軸方向ボルト」位置に作用することになり，

このためリングの応力は継手のないリング（一様リング と呼ぶ）よりも大きくなり，また異なった分布になると 考えられる。

現在のところ, セグメント リングの断面の設計は, 継 手のないリングといら仮定で行なわれており，したがっ て, 実際には一様リングの場合に比して大きい応力が作 用している可能性がある。

ここでは， 2 種類の形式 ( 6 個の継手と 4 個の継手を 持つ場合) のセグメントリングについて，2 軸対称な 外圧が作用し，かつ周囲には土などの支持がない場合を 最小仕事の原理によって解析し, 「軸方向ボルト」に作 用するせん断力, 七グメント リングの応力, たわみと継

* 正会員 工博 東京大学教授 生産技術研究所

**正会員石川島播磨重工 $\mathrm{KK}$ 技術研究所構造研究室
久 保 慶三 郎*・結 城 皓 脏** By Keizaburo Kubo and Teruhiro Yuki

手剛性との関係を求め, 一様 リングとの比較を行なっ た。さらに, 実験によって理論の妥当性を検証した。

\section{2. 解析の方法}

解析にあたりつぎのような仮定を行なう。

(1) セグメントリングは 図一1 のように「セグメ ント継手」を曲げモーメントに対してばねとして扱い, 継手剛性をばね定数で表わす。軸力, せん断力による継 手の変形はないものとする。

（2）「軸方向ボルト」の径に対して, ボルト穴のク リアランスは小さく, したがって相隣るリングは「軸方 向ボルト」位置で互いの変位は等しく, せん断力による ずれは生じないものとする。

(3) リングの変形が 2 軸対称の場合, 円周方向の成 分は半径方向の成分に比して小さいのでこれを無視す る。

（4）「セグメント継手」の曲げモーメントによる折 れ曲がりは微小変形とする。

（5） セグメント本体部の曲げ剛性は一定とし，七グ メントの厚さはリングの半径に比して十分小さいものと する。

（6）リングに作用する外圧は鉛直方向, 水平方向と もに長方形分布荷重とし, 鉛直方向荷重に対する水平方 向荷重の比は $\nu(<1.0)$ とする。

以上の仮定にもとづいて, 図一1 (b) のようにリング を模型化し, 外圧および「軸方向ボルト」位置に未知力 $Q$ が作用したときの「軸方向ボルト」位置の変位式を求 める。つぎに, 相隣るリングでは互いに $Q$ は大きさが

図一1 セグメントの模型化

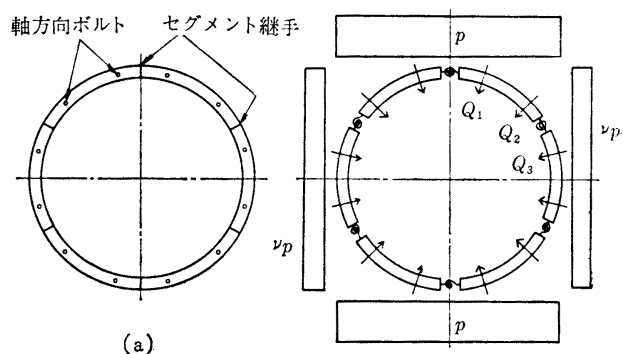

(b) 
等しく，向きが逆に作用していること，および「軸方向 ボルト」位置の変位が等しい条件より未知力 $Q$ が求め られる。

セグメントリングは 円周を 6 等分割した 6 個のセグ メントよりなるもの，および 4 等分割した 4 個のセグメ ントよりなるものの 2 種類のリングについて解析を行な う。

\section{3. 解 析}

円周を 6 等分割した 6 個のセグメントより成るリング で「軸方向ボルト」は各セグメントに 2 箇所あり，これ を「セグメント継手」がトンネル軸方向に通らないよう に千鳥に組まれた場合について解析する。

セグメントリングの半径を $R$, セグメント本体部の 曲代剛性を $E I$, 継手のば祮定数を $k$ として, 頂部に継

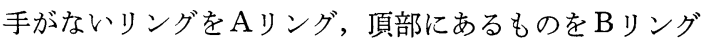
と呼ぶことにする。

外圧として, 鉛直方向荷重 $p$, 水平方向荷重 $\nu p$ なる 二軸対称な分布荷重を考えると，対称性より図一2のよ うにリングの $1 / 4$ だけとり出して考えることができる。

\section{図-2}
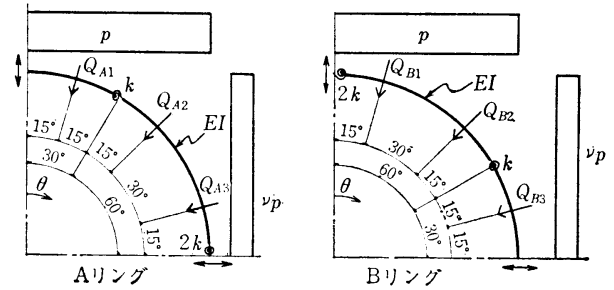

いま，「軸方向ボルト」位置に作用する力 $Q$ を既知と すると, リングの軸力, せん断力はつりあい式のみから 決定でき，A，B リングは一次不静定となる。

まず，Aリングについて考えて， $\theta=0$ における曲げ モーメント $M_{A}(0)$ をつぎのようにおく

$$
M_{A}(0)=\bar{M}_{A}(0)+X_{A}
$$

ただし，

$\bar{M}_{A}(\theta)$ : 一様リングの $\theta$ における曲げモーメント

$X_{A}:$ 不静定モーメント

そうすると, $\theta$ における曲げモーメント $M_{A}(\theta)$ は

$$
M_{A}(\theta)=\bar{M}_{A}(\theta)+X_{A}
$$

となる。ここで $\bar{M}_{A}(\theta)$ は次式で表わされる。

$$
\begin{aligned}
\bar{M}_{A}(\theta) & =D(\theta) p R^{2}+R \boldsymbol{S}(\theta) \boldsymbol{Q}_{A} \cdots \cdots \cdots \cdots(3) \\
D(\theta)^{1)} & =\frac{1}{4}(1-\nu) \cos 2 \theta \\
\left.\boldsymbol{S}(\theta)^{2}\right) & =\left[\begin{array}{ll}
S_{1}(\theta) & S_{2}(\theta) \quad S_{3}(\theta)
\end{array}\right] \\
S_{1}(\theta) & =\frac{2}{\pi}-\frac{1}{2}\left|\sin \left(\theta+\frac{\pi}{12}\right)\right|-\frac{1}{2}\left|\sin \left(\theta-\frac{\pi}{12}\right)\right| \\
S_{2}(\theta) & =\frac{2}{\pi}-\frac{1}{2}\left|\sin \left(\theta+\frac{\pi}{4}\right)\right|-\frac{1}{2}\left|\sin \left(\theta-\frac{\pi}{4}\right)\right| \\
S_{3}(\theta) & =\frac{2}{\pi}-\frac{1}{2}\left|\sin \left(\theta+\frac{5 \pi}{12}\right)\right|-\frac{1}{2}\left|\sin \left(\theta-\frac{5 \pi}{12}\right)\right|
\end{aligned}
$$

$$
\boldsymbol{Q}_{A}=\left[\begin{array}{c}
Q_{A_{1}} \\
Q_{A_{2}} \\
Q_{A_{3}}
\end{array}\right]
$$

対称性より, $\theta=0, \pi / 2$ の二つの点の相対回転角は 0 とならなければならないから

$$
\int_{0}^{\pi / 2} \frac{M_{A}(\theta)}{E I} R d \theta+\frac{M_{A}(\pi / 6)}{k}+\frac{M_{A}(\pi / 2)}{2 k}=0
$$

式 (2)を用いると上式は

$$
\begin{aligned}
& \int_{0}^{\pi / 2} \frac{\bar{M}_{A}(\theta)}{E I} R d \theta+\int_{0}^{\pi / 2} \frac{X_{A}}{E I} R d \theta \\
& +\frac{\bar{M}_{A}(\pi / 6)+X_{A}}{k}+\frac{\bar{M}_{A}(\pi / 2)+X_{A}}{2 k}=0 .
\end{aligned}
$$

となる。ここで

$$
\int_{0}^{\pi / 2} \frac{\bar{M}_{A}(\theta)}{E I} R d \theta=0
$$

であるから，式 (5) は

$$
\frac{\pi R}{2 E I} X_{A}+\frac{\bar{M}_{A}(\pi / 6)+X_{A}}{k}+\frac{\bar{M}_{A}(\pi / 2)+X_{A}}{2 k}=0
$$

これより，不静定モーメント $X_{A}$ はつぎのようにな る。

$$
\begin{aligned}
& X_{A}=K\left\{\bar{M}_{A}(\pi / 6)+\frac{1}{2} \bar{M}_{A}(\pi / 6)\right\} \\
& =K R\left(H_{\boldsymbol{A}} p R+\boldsymbol{C}_{\boldsymbol{A}} \boldsymbol{Q}_{\boldsymbol{A}}\right) \\
& \text { ここで, } \\
& K=-\frac{1}{\lambda+3 / 2} \\
& \lambda=\frac{\pi R k}{2 E I} \quad \text { (継手剛比) } \\
& H_{A}=D\left(\frac{\pi}{6}\right)+\frac{1}{2} D\left(\frac{\pi}{2}\right) \\
& \boldsymbol{C}_{A}=\boldsymbol{S}\left(\frac{\pi}{6}\right)+\frac{1}{2} \boldsymbol{S}\left(\frac{\pi}{2}\right)
\end{aligned}
$$

つぎに,「軸方向ボルト」位置 ( $Q$ の作用点) の変位 を求める。 $Q_{A N}(N=1,2,3)$ の作用点の変位を $d_{A N}$ と すると，最小仕事の原理により

$$
\begin{aligned}
d_{A N} & =\int_{0}^{\pi / 2} \frac{M_{A}(\theta)}{E I} \cdot \frac{\partial M_{A}(\theta)}{\partial Q_{A N}} R d \theta \\
& +\frac{1}{k} M(\pi / 6) \frac{\partial M_{A}(\pi / 6)}{\partial Q_{A N}}+\frac{1}{2 k} M_{A}(\pi / 2) \frac{\partial M_{A}(\pi / 2)}{\partial Q_{A N}} \\
= & \frac{1}{E I} \int_{0}^{\pi / 2}\left(\bar{M}_{A}(\theta)+X_{A}\right)\left(\frac{\partial \bar{M}_{A}(\theta)}{\partial Q_{A N}}+\frac{\partial X_{A}}{\partial Q_{A N}}\right) R d \theta \\
& +\frac{1}{k}\left(\bar{M}_{A}(\pi / 6)+X_{A}\right)\left(\frac{\partial \bar{M}_{A}(\theta)}{\partial Q_{A N}}+\frac{\partial X_{A}}{\partial Q_{A N}}\right) \\
& +\frac{1}{2 k}\left(\bar{M}_{A}(\pi / 2)+X_{A}\right)\left(\frac{\partial \bar{M}_{A}(\theta)}{\partial Q_{A N}}+\frac{\partial X_{A}}{\partial Q_{A N}}\right)
\end{aligned}
$$

ここで,

$$
\left.\begin{array}{l}
\int_{0}^{\pi / 2} \bar{M}_{A}(\theta) \frac{\partial X_{A}}{\partial Q_{A N}} R d \theta=\frac{\partial X_{A}}{\partial Q_{A N}} \int \bar{M}_{A}(\theta) R d \theta=0 \\
\int_{0}^{\pi / 2} X_{A} \frac{\partial \bar{M}_{A}(\theta)}{\partial Q_{A N}} R d \theta=X_{A} \int \frac{\partial \bar{M}_{A}(\theta)}{\partial Q_{A N}} R d \theta=0
\end{array}\right\}
$$


である。また式 (3), 式 (5) より

$$
\left.\begin{array}{l}
\frac{\partial \bar{M}_{A}(\theta)}{\partial Q_{A N}}=R S_{N}(\theta) \\
\frac{\partial X_{A}}{\partial Q_{A N}}=K R C_{A N}=K R\left\{S_{N}(\pi / 6)+\frac{1}{2} S_{N}(\pi / 2)\right\}
\end{array}\right\}
$$

式 (8)，(9)を用い，また

$$
\begin{aligned}
\int_{0}^{\pi / 2} & \bar{M}_{A}(\theta) \frac{\partial \bar{M}_{A}(\theta)}{\partial Q_{A N}} R d \theta \\
& =R^{3} \int_{0}^{\pi / 2}\left\{D(\theta) p R+\boldsymbol{S}(\theta) \boldsymbol{Q}_{A}\right\} S_{N}(\theta) d \theta \\
& =R^{3}\left(T_{N} p R+\boldsymbol{F}_{N} \boldsymbol{Q}_{A}\right) \ldots \ldots \ldots \ldots \ldots \ldots \ldots . \cdots \cdots
\end{aligned}
$$

とおいて式 (7) を書き改めると，

$$
\begin{aligned}
& d_{A N}=\frac{R^{3}}{E I}\left(T_{N} p R+\boldsymbol{F}_{N} \boldsymbol{Q}_{A}\right)+\frac{\pi}{2} \frac{R^{3}}{E I} K\left(H_{A} p R+\boldsymbol{C}_{A} \boldsymbol{Q}_{A}\right) K C_{A N} \\
& +\frac{1}{k} R^{2}\left(D(\pi / 6) p R+\boldsymbol{S}(\pi / 6) \boldsymbol{Q}_{A}+K H_{A} p R+K \boldsymbol{C}_{A} \boldsymbol{Q}_{A}\right)\left(S_{N}(\pi / 6)+K C_{A N}\right) \\
& +\frac{1}{2 k} R^{2}\left(D(\pi / 2) p R+\boldsymbol{S}(\pi / 2) \boldsymbol{Q}_{A}+K H_{A} p R+K \boldsymbol{C}_{A} \boldsymbol{Q}_{A}\right)\left(S_{N}(\pi / 2)+K C_{A N}\right) \\
& =\frac{R^{3}}{E I}\left[T_{N} p R+\boldsymbol{F}_{N} \boldsymbol{Q}_{A}+\frac{\pi}{2} K\left(H_{A} p R+\boldsymbol{C}_{A} \boldsymbol{Q}_{A}\right) K C_{A N}\right. \\
& +\frac{\pi}{2} \frac{1}{\lambda}\left\{\left(D(\pi / 6)+K H_{A}\right) p R+\left(\boldsymbol{S}(\pi / 6)+K \boldsymbol{C}_{A}\right) \boldsymbol{Q}_{A}\right\}\left(S_{N}(\pi / 6)+K C_{A N}\right) \\
& \left.+\frac{\pi}{4} \frac{1}{\lambda}\left\{\left(D(\pi / 2)+K H_{A}\right) p R+\left(\boldsymbol{S}(\pi / 2)+K \boldsymbol{C}_{A N}\right) \boldsymbol{Q}_{A}\right\}\left(S_{N}(\pi / 2)+K C_{A N}\right)\right] \\
& =\frac{R^{3}}{E I}\left[T_{N}+\frac{\pi}{2} K^{2} H_{A} C_{A N}+\frac{\pi}{2} \frac{1}{\lambda}\left(D(\pi / 6)+K H_{A}\right)\left(S_{N}(\pi / 6)+K C_{A N}\right)\right. \\
& \left.+\frac{\pi}{4} \frac{1}{\lambda}\left(D(\pi / 2)+K H_{A}\right)\left(S_{A}(\pi / 2)+K C_{A N}\right)\right] p R \\
& +\frac{R^{3}}{E I}\left[\boldsymbol{F}_{N}+\frac{\pi}{2} K^{2} \boldsymbol{C}_{A} C_{A N}+\frac{\pi}{2} \frac{1}{\lambda}\left(\boldsymbol{S}(\pi / 6)+K \boldsymbol{C}_{\boldsymbol{A}}\right)\left(S_{N}(\pi / 6)+K C_{A N}\right)\right. \\
& \left.+\frac{\pi}{4} \frac{1}{\lambda}\left(\boldsymbol{S}(\pi / 2)+K \boldsymbol{C}_{\boldsymbol{A}}\right)\left(S_{N}(\pi / 2)+K C_{\boldsymbol{A N}}\right)\right] \boldsymbol{Q}_{\boldsymbol{A}}
\end{aligned}
$$

ここで， $T_{N}, \boldsymbol{F}_{N}$ はそれぞれ一様リングの土圧， $\boldsymbol{Q}$ による $Q_{N}$ 作用点の変位をあらわしており,つぎのよ らになる。

$$
\begin{aligned}
& T_{1}=t \cos (\pi / 6) \\
& T_{2}=t \cos (\pi / 2) \\
& T_{3}=t \cos (5 \pi / 6)
\end{aligned}
$$
ただし，

$$
t=\frac{(1-\nu) p R^{4}}{12 E I}
$$$$
\boldsymbol{F}^{T}{ }_{1}=\left[\begin{array}{l}
f(0)+f(\pi / 6) \\
f(\pi / 6)+f(\pi / 3) \\
f(\pi / 3)+f(\pi / 2)
\end{array}\right]
$$$$
\boldsymbol{F}_{2}{ }_{2}=\left[\begin{array}{l}
f(\pi / 6)+f(\pi / 3) \\
f(0)+f(\pi / 2) \\
f(\pi / 6)+f(\pi / 3)
\end{array}\right]
$$$$
\boldsymbol{F}^{T}{ }_{3}=\left[\begin{array}{l}
f(\pi / 3)+f(\pi / 2) \\
f(\pi / 6)+f(\pi / 3) \\
f(0)+f(\pi / 6)
\end{array}\right]
$$

ただし，

$$
f(\theta)=-\frac{1}{\pi}+\frac{1}{4}\left(\frac{\pi}{2}-\theta\right) \cos \theta+\frac{1}{4} \sin (\theta)
$$

Bリングについても同様にして

$$
\boldsymbol{Q}_{B}=\left[\begin{array}{l}
Q_{B_{1}} \\
Q_{B_{2}} \\
Q_{B_{3}}
\end{array}\right]
$$$$
M_{B}(\theta)=\bar{M}_{B}(\theta)+X_{B}
$$$$
\bar{M}_{B}(\theta)=D(\theta) p R^{2}+R \boldsymbol{S}(\theta) \boldsymbol{Q}_{B}
$$

$$
\begin{aligned}
X_{B} & =K\left\{\frac{1}{2} \bar{M}_{B}(0)+M_{B}(\pi / 3)\right\} \\
& =K R\left(H_{B} p R+\boldsymbol{C}_{B} \boldsymbol{Q}_{B}\right)
\end{aligned}
$$

ここで,

$$
\begin{aligned}
& H_{B}=\frac{1}{2} D(0)+D(\pi / 3) \\
& \boldsymbol{C}_{B}=\frac{1}{2} \boldsymbol{S}(0)+\boldsymbol{S}(\pi / 3)
\end{aligned}
$$

$Q_{B N}$ の作用点の変位を $d_{B N}$ とおいて

$$
\begin{aligned}
d_{B N} & =\frac{R^{3}}{E I}\left[T_{N}+\frac{\pi}{2} K^{2} H_{B} C_{B N}\right. \\
+ & \frac{\pi}{4} \frac{1}{\lambda}\left(D(0)+K H_{B}\right)\left(S_{N}(0)+K C_{B N}\right) \\
+ & \left.\frac{\pi}{2} \frac{1}{\lambda}\left(D(\pi / 3)+K H_{B}\right)\left(S_{N}(\pi / 3)+K C_{B N}\right)\right] p R \\
& +\frac{R^{3}}{E I}\left[\boldsymbol{F}_{N}+\frac{\pi}{2} K^{2} C_{B} C_{B N}\right. \\
& +\frac{\pi}{2} \frac{1}{\lambda}\left(\boldsymbol{S}(0)+K C_{B}\right)\left(S_{N}(0)+K C_{B N}\right) \\
& \left.+\frac{\pi}{2} \frac{1}{\lambda}\left(\boldsymbol{S}(\pi / 3)+K C_{B}\right)\left(S_{N}(\pi / 3)+K C_{B N}\right)\right] \boldsymbol{Q}_{B}
\end{aligned}
$$

が得られる。

A リングと Bリングは「軸方向ボルト」で結合されて いるから，この点で互いに変位は等しい。また「軸方向 ボルト」に作用する力はそれぞれのリングで大きさが等 しく, 方向が逆に作用していることから, 式 (11), (11)' に氺いて 


$$
\begin{aligned}
& d_{A N}=d_{B N} \\
& \boldsymbol{Q}_{A}=-\boldsymbol{Q}_{B}=\boldsymbol{Q}
\end{aligned}
$$

ただし，

$$
\boldsymbol{Q}=\left[\begin{array}{l}
Q_{1} \\
Q_{2} \\
Q_{3}
\end{array}\right] \quad \text { とおくと }
$$

$\left[2 \boldsymbol{F}_{N}+\frac{\pi}{2} K^{2}\left(C_{A N} \boldsymbol{C}_{A}+D_{B N} \boldsymbol{C}_{B}\right)+\frac{\pi}{4} \frac{1}{\lambda}\left(S_{N}(0)+K C_{B N}\right)\left(\boldsymbol{S}(0)+K C_{B}\right)\right.$

$+\frac{\pi}{2} \frac{1}{\lambda}\left(S_{N}(\pi / 6)+K C_{A N}\right)\left(\boldsymbol{S}(\pi / 6)+K \boldsymbol{C}_{A}\right)+\frac{\pi}{2} \frac{1}{\lambda}\left(S_{N}(\pi / 3)+K C_{B N}\right)\left(\boldsymbol{S}(\pi / 3)+K \boldsymbol{C}_{B}\right)$

$\left.+\frac{\pi}{4} \frac{1}{\lambda}\left(S_{N}(\pi / 2)+K C_{A N}\right)\left(\boldsymbol{S}(\pi / 2)+K \boldsymbol{C}_{A}\right)\right] \boldsymbol{Q}+\left[\frac{\pi}{2} K^{2}\left(H_{A N} C_{A N}-H_{B N} C_{B N}\right)\right.$

$-\frac{\pi}{4} \frac{1}{\lambda}\left(S_{N}(0)+K C_{B N}\right)\left(D(0)+K H_{B}\right)+\frac{\pi}{2} \frac{1}{\lambda}\left(S_{N}(\pi / 6)+K C_{A N}\right)\left(D(\pi / 6)+K H_{A}\right)$

$\left.-\frac{\pi}{2} \frac{1}{\lambda}\left(S_{N}(\pi / 3)+K C_{B N}\right)\left(D(\pi / 3)+K H_{B}\right)+\frac{\pi}{4} \frac{1}{\lambda}\left(S_{N}(\pi / 2)+K C_{A N}\right)\left(D(\pi / 2)+K H_{A}\right)\right] p R=0 \cdots$

式 (15) は $N=1,2,3$ の三元連立方程式とな り, これを解けば $\boldsymbol{Q}\left(Q_{1}, Q_{2}, Q_{3}\right)$ が定まる。

この $\boldsymbol{Q}$ の值を用いれば, リングの応力, た わみを求めることができる。

以上は 6 セグメントリングについて解析し たが，他種のリングについても同様の方法で解 析できる。

\section{4. 計算結果}

「セグメント継手」の継手剛比入の種々の值 に対して $Q$ を計算し, その結果を図一3に示 す。ただし，「軸方向ボルト」に作用するせん 断力は $Q / 2$ である。

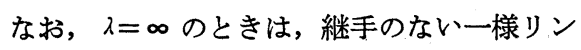
グと一致する。

継手剛比の低下によって付加される応力, す なわち, 一様リングとの差は図一4, 図一5, 図 一6のようになり, それぞれ付加モーメント， 付加軸力, 付加せん断力を示している。また, リングの上下方向のたわみ (A リングの鉛直方 向の直径の減少量) は図一7のようになる。

ここでとりあげた 6 セグメントリングは継 手剛比入が 0 になると不安定となり, 解は存在 しないのでスの值は 0.0001 まで計算を行なっ た。

この結果, $\lambda$ の值が減少するにしたがって, $Q$ の值および付加たわみは増大し, スが 8.0 9.0 以下になると急激に増大することがわか る。またリングの応力についても同様の傾向が あり、スが 0 に近づくと曲げモーメントの最大 值は一様リングのほぼ 2 倍になっている。

4 セグメントリングについても同様の計算 を行ない，その結果を図一8〜図一12に示す。 この場合は $\lambda=0$ のとき Bリングは不安定とな るが，Aリングはここで考えている土圧分布に 関するかぎり安定であるため解は存在する。

計算結果は 6 セグメント リングの場合と同

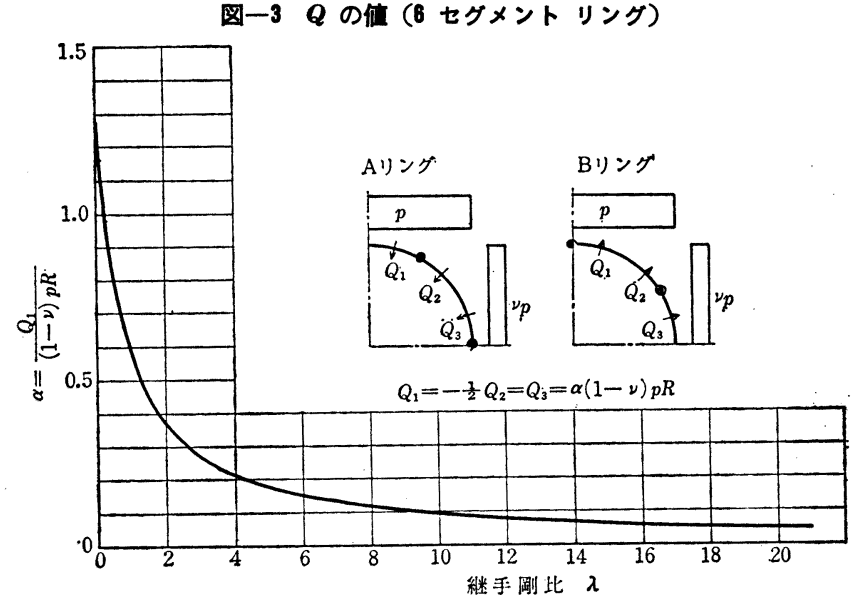

図一4付加曲げモーメント（6 セグメントリング）

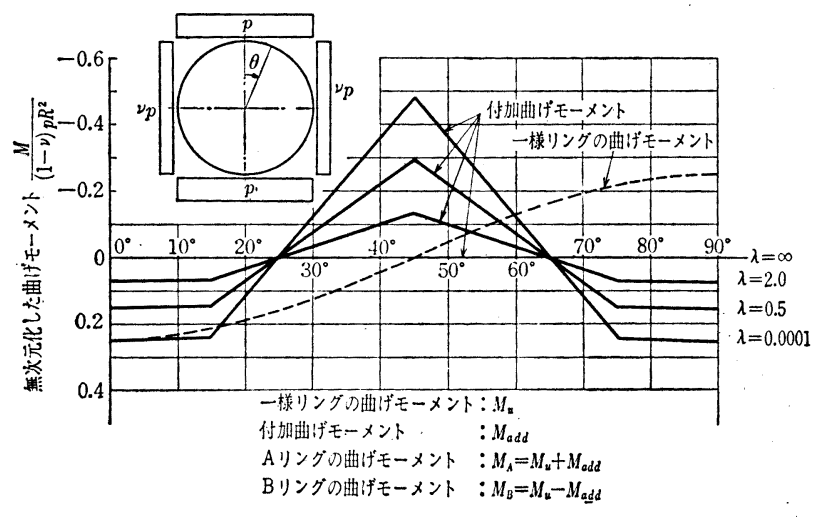

図一5 付加軸力（6 セグメント リング）

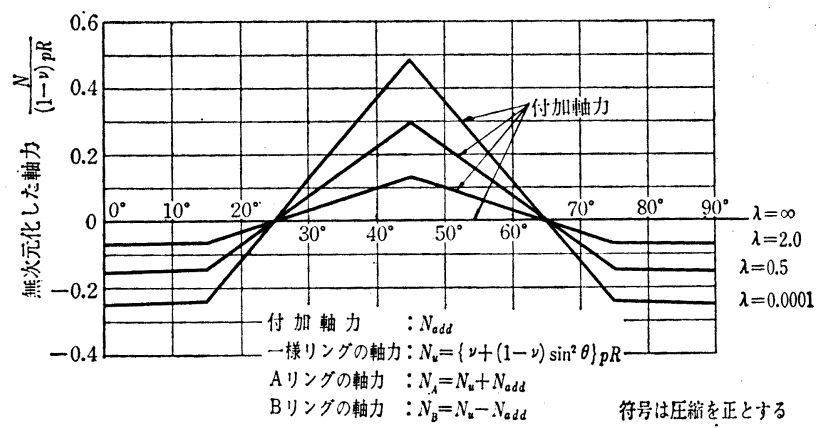


図-6 付加せん断カ（6 セグメント リング）

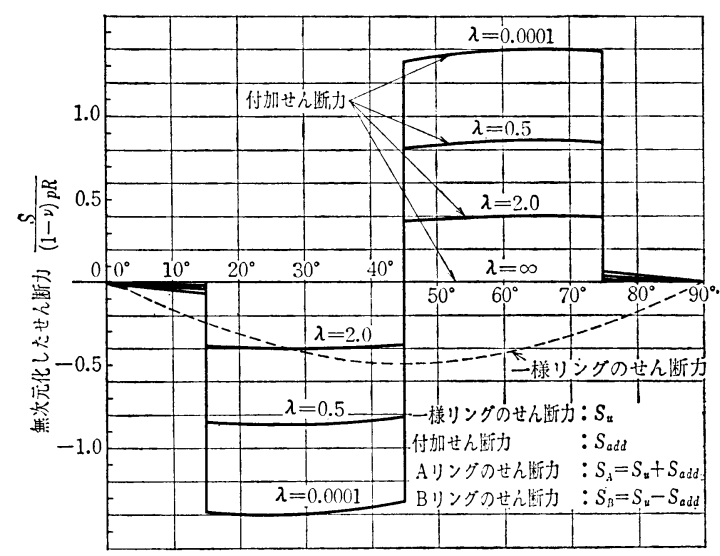

図一7付加たわみ（6 セグメントリング）

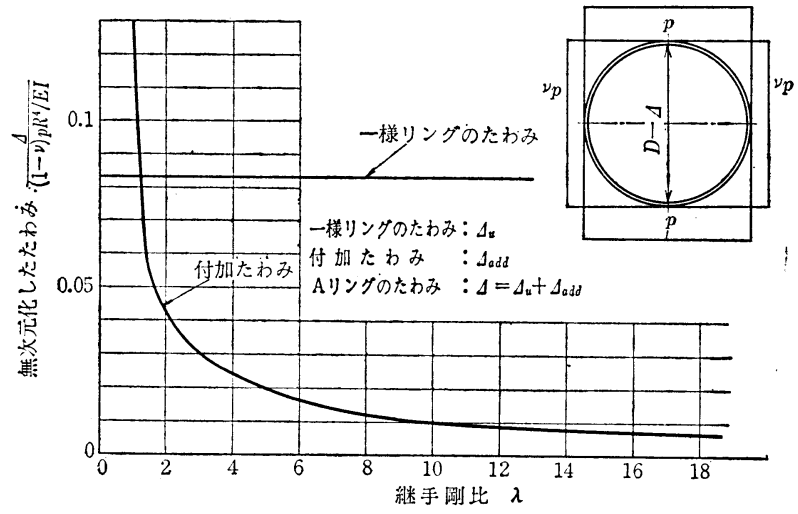

図一8Ｑの值（4 セグメントリング）

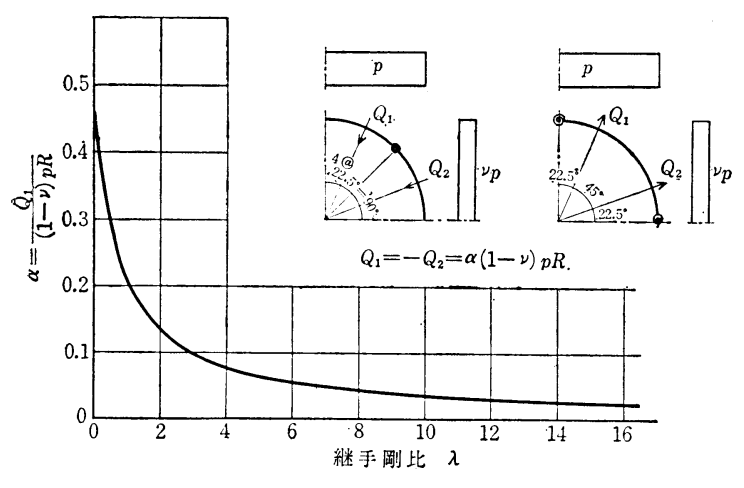

図一9 付加曲げモーメント（4 セグメントリング）

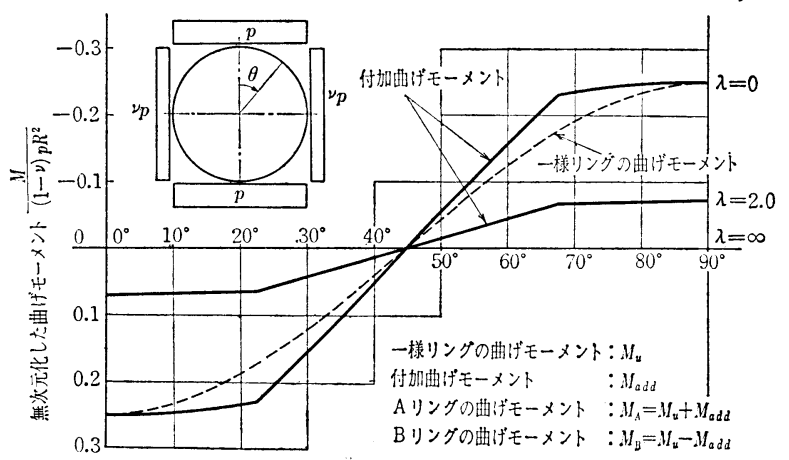


図一10 付加軸力（4 セグメントリング）

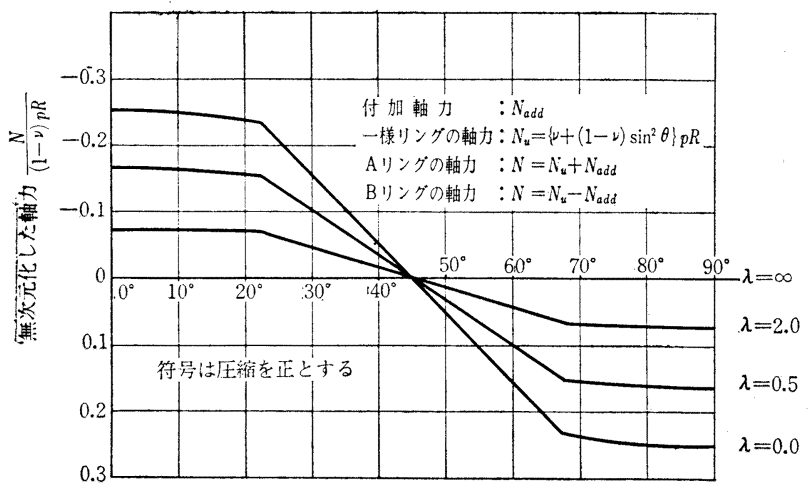

図一11 付加せん断力（4 セグメントリング）

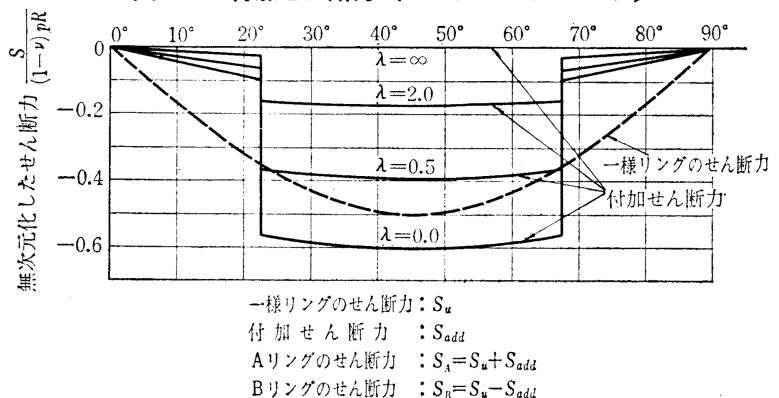

図一12 付加たわみ（4 セグメントリング）

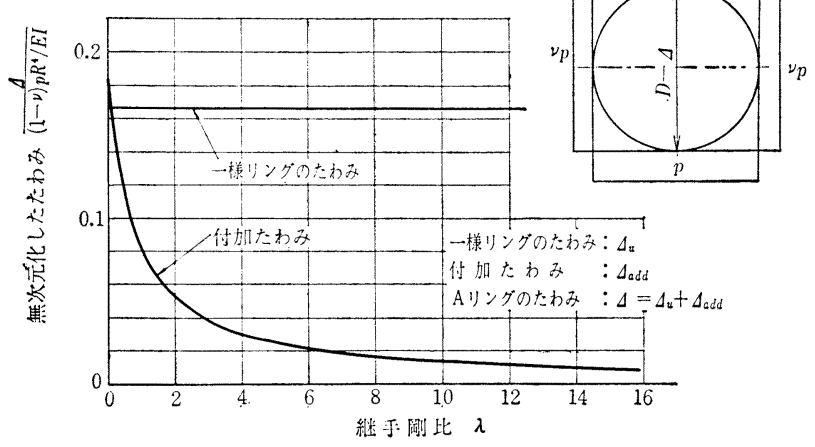

様に, $\lambda$ の減少にしたがって $Q$, 付加たわみともに増大 し，入が 8.0 9.0 以下では急激に増大する。また 0 のとき, 最大曲げモーメントは一様リングの 2 倍とな る。

6 セグメント リングと 4 セグメント リングを比較す ると, $Q$ の值および最大せん断力は前者が後者の約 2 倍になっている。たわみおよび最大曲げモーメントは両 者の間の差は小さい。

\section{5. 実験}

解析に用いた理論の妥当性を検証するためにリング模 型を製作して載荷試験を行なった。

\section{(1) 試 験 体}

試験体は 6 セグメントより成るリングとして 図一13
図-13 試 験 体

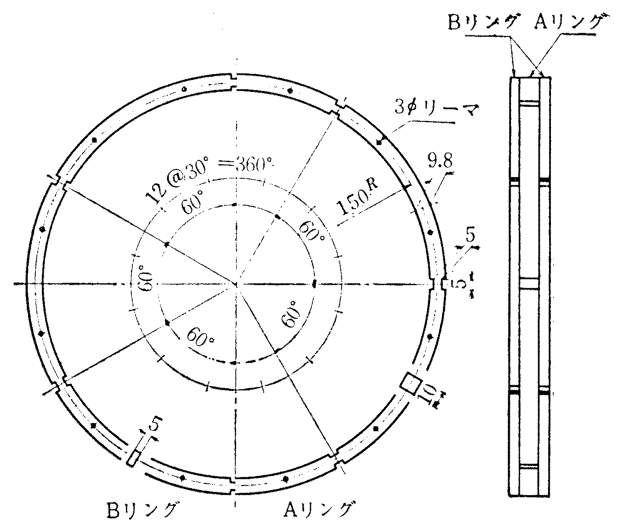

に示す Aリングと Bリングを製作し，「セグメン ト継手」に相当するものとして，その位置に切欠 きを設けて継手の剛性を低下させた。

A リングと B リングは「セグメント継手」が重 ならないように，Aリングをはさんで両側から B リングを重ね，リーマボルトで連結した。

試験体の要目はつぎのようである。

材質 : SS

半径 : $150 \mathrm{~mm}$

幅 : $10 \mathrm{~mm}$ ( $\mathrm{A}$ リング), $5 \mathrm{~mm}$ ( $\mathrm{B}$ リング). 厚さ : $9.8 \mathrm{~mm}(9.7 \sim 9.9$ の範囲にあり平均 $9.8 \mathrm{~mm}$ )

切欠部の長さ : $5 \mathrm{~mm}$

切欠部の厚さ : $5 \mathrm{~mm}$

\section{(2) 試験方法}

荷重として，土圧による分布荷重の代わりに試 験体の上下端から $15^{\circ}$ の「軸方向ボルト」位置に おけるリング中心に向から集中荷重を採用し，図 -14 に示すような 4 点集中荷重によって実験を 行なった。

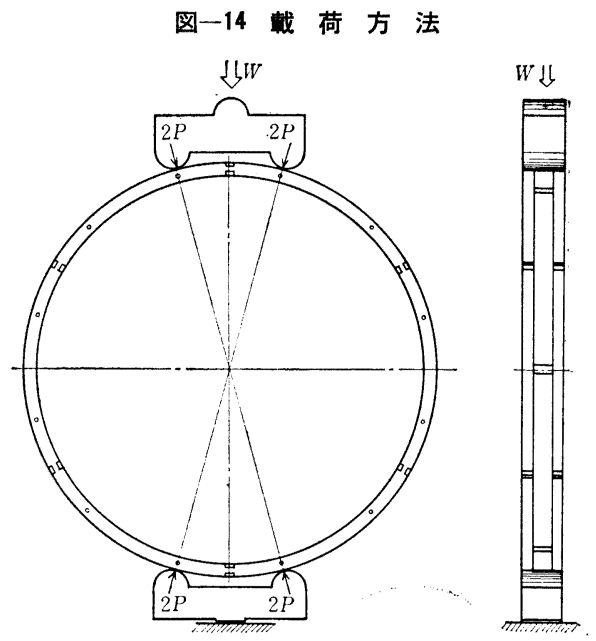


写真一1 試 験 装 置

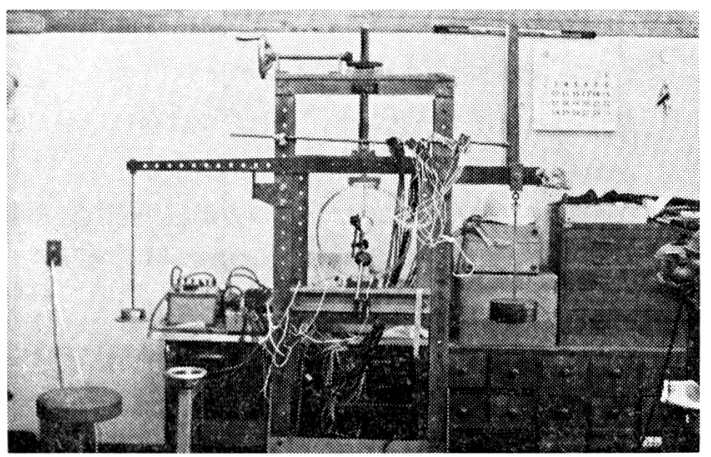

試験装置は写真一1のようにテコを利用しておもりで 載荷するようになっており

w：おもりの重量

とすれば

$W=4 w$

となり，A，B 各リングには

$P=\frac{1}{4} W \sec 15^{\circ}$

なる集中荷重が作用することになる。

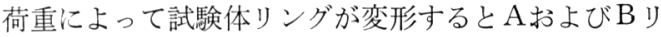
ングは互いに拘束し合い, リングの応力, たわみはその 影響を受けることになる。

たわみの測定はＢリングの上下端の変位を $1 / 1000$ $\mathrm{mm}$ ダイアルゲージを用いて測定して直径の変化量を 求めた。

リングのひずみは抵抗線ひずみ計 (ゲージ長さ $3 \mathrm{~mm}$ )

図一15Ａリングのたわみ実験結果

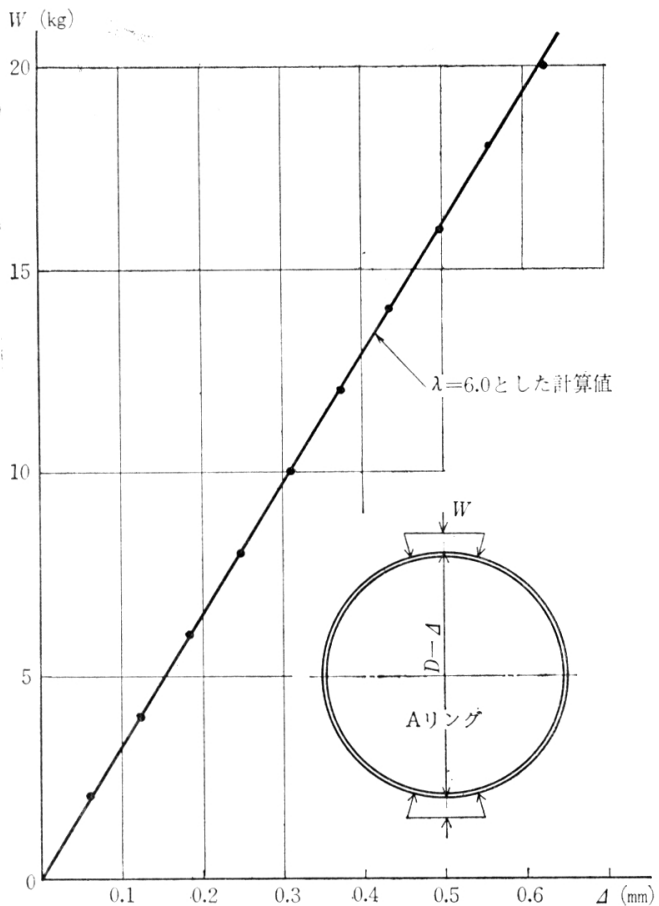

を頂点から $15^{\circ}$ おきに $90^{\circ}$ まで貼付して計測した。ただ し荷重点と切欠部では $15^{\circ} / 4$ だけずらした。

なお, 弾性範囲内で試験をするために切久部が降伏し ないよう最大ひずみが $250 \times 10^{-6}$ を超えない範囲で載 荷した。

\section{(3) 実験結果およで考察}

試験体リングの「セグメント継手」のばね定数 $k$ ，し たがって，継手剛比 $\lambda(=\pi R k / 2 E I)$ の值を求めるため にAリングのみとりだして載荷し，たわみを測定した。 その結果を図一15 に示寸。

図一15 によると実験值は $\lambda=6.0$ とした計算值に一 致しており，したがって本試験に用いた試験体リングの 継手剛比は

A，Bリングを千鳥に重ねた試験体の実験結果は，た わみ（鈆直方向の直径の変化）を 図一16に, ひずみの 分布を 図一17 に示し, 同時に $\lambda=6.0$ の理論值および

\section{図一16 たわみ実験結果}

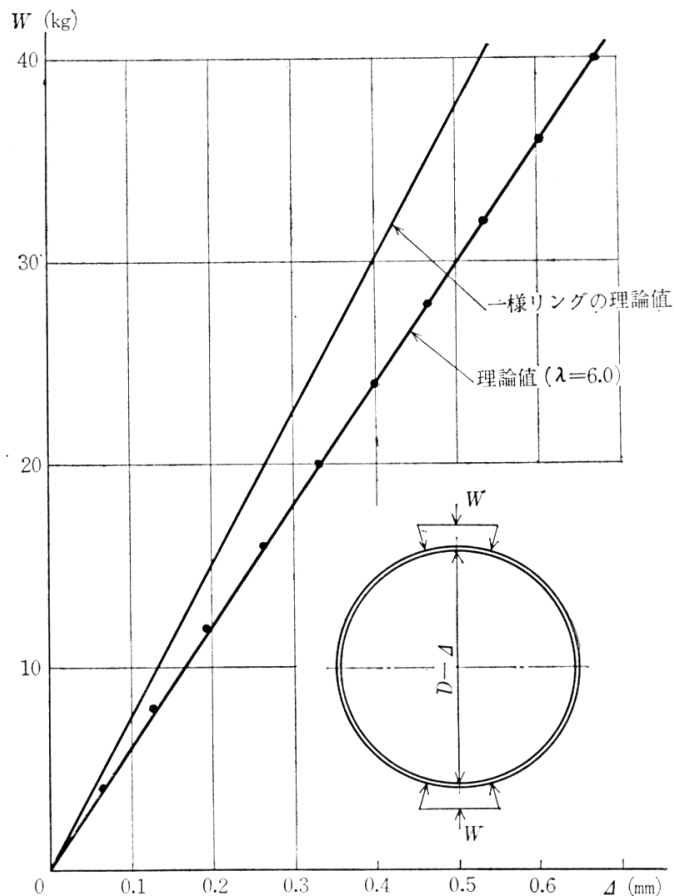

図一17W=40 kg におけるひずみの分布

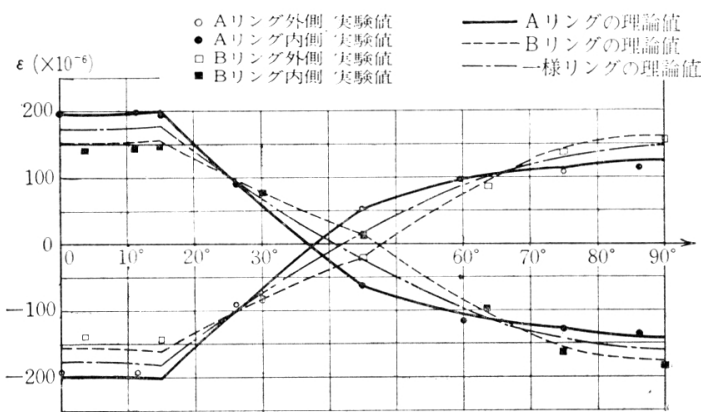


継手のない一様リングの理論值を併記してある。

たわみの実験值は理論值とよく一致し，一様リングの

場合より約 $26 \%$ 大きくなっている。

ひずみの実験值も理論值とよく一致し，ひずみの最大 值は一様リングの場合より約 $14 \%$ 大きくなっている。 たわみ，ひずみともに実験值はよく直線性を示してお り，試験体の精度は良好であった。

\section{6. 結}

\section{論}

以上の二軸対称荷重の場合の理論計算および実験結果 からつぎのことが明らかになった。

1）ここで用いた理論は実験結果とよく一致し, 理論 の妥当性は証明された。

2)「セグメント継手」の継手剛比が $\lambda=\infty$ では継手 のない一様リングと一致するが， $\lambda<\infty$ では「軸方 向ボルト」にせん断力が作用し, この值は $\lambda$ の減少 にしたがって増大する。

3）リングの応力分布は入が小さくなると前記のせん 断力の影響で一様リングと異なった分布となり，曲 げモーメントの最大值は $\lambda \approx 0$ では一様リングの場 合の約 2 倍になる。

4) リングのたわみも応力と同様に入の減少にしたが って増加する。

5）応力, たわみ, 「軸方向ボルト」に作用するせん 断力は，ここで採用した条件に関しては， $\lambda>9.0$ ではほとんど変化なく, 一様リングとの差は小さい が, $\lambda<9.0$ では $\lambda$ の減少にしたがって急激に増加 する。

6) 以上のことから,$\lambda<9.0$ のセグメントリング
ではスの低下による応力, たわみなどの増加を考慮 する必要がある。

7） 6 セグメントリングと 4 セグメントリングを比 較すると曲げモーメント，たわみでは差はほとんど みられないが,「軸方向ボルト」のせん断力, リン グの軸力, せん断力では前者の方が継手剛性の影響 が大きい。

\section{7.おわりに}

ここでは，2 軸対称な外压を受ける場合のセグメント リングについて解析を行なったが, 実際のトンネルに作 用する土圧の様子は不明な点が多く, このように簡単な 取り扱いで十分とは考えられない。しかし，この研究の 結果, 継手剛性とセグメントの応力の関係について, 少 なくとも定性的な結論は得られたと思う。今後さらにで きるだけ実際に近い土圧に対して解析を行ないたいと思 っている。

数值計算の一部は石川島播磨重工 UNIVAC-1107 電 子計算機を使用した。

最後に, 本研究を進めるにあたりご協力いただいた石 川島播磨重工技術研究所 秋田好雄博士, 前田豊生博士, 藤井登喜男氏ならびに実験を手伝っていただいた安藤紘 三君に感謝の意を表します。

\section{参 考 文 献}

1）湯浅欽史：たわみ性地下埋設管の窒内実験, 土木学会論 文集, 99 号, pp. 9

2）強度設計データブック，裳華房，pp. 439

3) Henry L. Langhaar: Energy Methods in Applied Mechanics, John Wiley and Sons, Inc.

(1967.7.12 - 受付) 